Bangladesh J. Bot. 42(2): 307-314, 2013 (December)

\title{
POLLINIUM DEVELOPMENT IN SPIRANTHES SINENSIS (PERS.) AMES. AND CYMBIDIUM PENDULUM SW: A COMPARATIVE STUDY
}

\author{
Ravi Kant* ${ }^{*}$ Mohammad Musharof Hossain ${ }^{1}$ and Lucky K Attri ${ }^{2}$ \\ Department of Botany, Panjab University, Chandigarh-160 014, India
}

Key words: Pollinia, Cymbidium pendulum, Spiranthes sinensis, Orchidaceae

\begin{abstract}
Comparative studies on the early anther development, anther wall differentiation, pollinium development and pollen grains surface features in Spiranthes sinensis (Pers.) Ames. (a terrestrial orchid) and Cymbidium pendulum Sw. (an epiphytic orchid) using light and scanning electron microscopy were described. Anther primordium initiated as a homogenous mass of meristematic cells which developed two thecae, each with a group of archesporial cells of dense cytoplasmic contents. The sporogenous cells of the hypodermal layer formed the anther wall which was 4-5 layered in S. sinensis and 7-layered in C. pendulum. The rare feature of 2-layered endothecium in $S$. sinensis and a 2-layered tapetum in $C$. pendulum was reported. Papillate epidermis was observed in C. pendulum. A complete septum of sterile cells in S. sinensis and partial in $C$. pendulum was observed. Pollen grains were mono-aperturate, reticulate and shed as tetrads in S. sinensis while either monoaperturate or inaperturate, tectate pollen grains and dispersed as hard pollinia in C. pendulum. This is a see-through information for accurate classification and phylogenetic reconstructions of orchid species.
\end{abstract}

\section{Introduction}

Spiranthes sinensis (Pers.) Ames., belongs to the subfamily Orchidoideae (tribe Cranichideae), distributed in cool growing regions of Himalaya, India, Afghanistan, Australia, China, Japan, Malaysia and New Zealand. It is an important medicinal herb in the Ayurvedic system of medicine. The roots are used as aphrodisiac and to cure various diseases like hemoptysis, headache, meningitis and chronic dysentery (Gutierrez 2010). On the other hand, Cymbidium pendulum Sw. is a member of the subfamily Epidendroideae (tribe Cymbidieae), sporadically distributed in the warm to cool growing regions of Chinese Himalayas, eastern and western Himalayas, and extends towards Australia. Due to perpetual flowers, large size and attractive luster it has high potential in cut flower production. It is also used in the traditional system of medicine, as purgative, demulcent and anti-inflammatory agent (Yoganarasimhan 1996).

Orchidaceae is the largest and highly evolved family of the flowering plants has been divided into 5 subfamilies viz. Apostasioideae, Cypripedioideae, Vanilloideae, Orchidoideae and Epidendroideae based on the peculiarities of anther characteristics such as number and position of anther on the column, orientation, number and morphology of the pollinia, types of shedding units, pollen texture and sculpturing (Cameron et al. 1999). But, earlier works on orchid embryology mainly focused on the development of female gametophyte and embryo (Swamy 1949, Bhanwra et al. 2006a, Gurudeva and Govindappa 2008) and a little information is available on pollinium and pollen development. Therefore, the present research was undertaken to study the early anther development, anther wall differentiation and its associated changes, and pollinium development in Spiranthes sinensis (Pers.) Ames. and Cymbidium pendulum Sw.

*Author for correspondence: <ravi.puchd@gmail.com>. Present address: Shoolini Institute of Life Sciences and Business Management, Solan, H. P. 173212, India. ${ }^{1}$ Department of Botany, University of Chittagong, Chittagong-4331, Bangladesh. ${ }^{2}$ Present address: Department of Botany, Dolphin PG College of Life Sciences, Punjab, India. 


\section{Material and Methods}

Mature plants of Spiranthes sinensis were collected from hilly forest of 'Fagu' near Shimla, the capital city of Himachal Pradesh, India (mean sea level $2460 \mathrm{~m}, 32^{\circ} 29^{\prime} \mathrm{N}$ and $75^{\circ} 10^{\prime} \mathrm{E}$ ) at its flowering season (June to August, 2009-2010) and maintained in the greenhouse of the Department of Botany, Panjab University, Chandigarh, India and C. pendulum were collected from the Orchid House of P. N. Mehra Botanical Garden of Panjab University, Chandigarh, India (mean sea level $300 \mathrm{~m}, 30^{\circ} 43^{\prime} \mathrm{N}$ and $77^{\circ} 13^{\prime} \mathrm{E}$ ) in its flowering season (March to May, 2010).

Flower buds and blooming flowers at different stages of development were collected between 7 and 11 a.m. and fixed in formalin-acetic acid-alcohol (FAA; $1 \mathrm{ml}$ formalin: $1 \mathrm{ml}$ acetic acid: 18 $\mathrm{ml} 50 \%$ ethanol) solution for 48 hours and stored in 70\% ethanol. Dehydration of materials was done in TBA (tertiary butyl alcohol) series. Section cutting, staining and slide preparation was done according to Kant and Hossain (2010). The permanent slides were prepared through mounting the sections with DPX (mixture of distyrene, a plastilizer and xylene). For studying pollinium morphology and pollen surface features, fresh pollinarium units and pollen grains were fixed in $2 \%$ glutraldehyde, $2.5 \%$ p-formaldehyde in $0.05 \%$ phosphate buffer, and then fixed in $1 \%$ osmium tetroxide. Dehydration was done through a series of acetone. After critical point drying and gold coating, the samples were examined under JEOL, JSM 600 Scanning Electron Microscope (SEM) according to Vij et al. (1992).

\section{Results and Discussion}

The flowers of S. sinensis were pink-coloured, slightly opened, glandular, spirally arranged on a $\sim 15 \mathrm{~cm}$ long attractive spike (Fig. 1a). Anther was single and erect. The pollinarium unit consists of 2 bipartite pollinia attached to sticky viscidium (Fig. 1b). The inflorescence of C. pendulum was up to $40 \mathrm{~cm}$ long, bearing 15 to 35 dark purplish flowers (Fig. 1c) loosely arranged on the flower axis. Anther was single and incumbent. Pollinarium unit consists of 2 hollow pollinia attached to the sticky viscidium (Figs 1d, e).

Notable inter-specific variations in anther wall differentiation, pollinium development and pollen micromorphology were observed. Anther primordium consisted of a mass of meristematic cells surrounded by a protoderm in both species. It was nearly rectangular in S. sinensis (Fig. 1f) while kidney-shaped in C. pendulum (Fig. 1g). Anther primordium developed two lateral thecae, oriented towards the labellum and each theca consisted with a mass of uniform sized cells of dense cytoplasmic contents, designated as archesporial cells (Figs 1h, i). These observations support earlier reports in some other orchids representing the subfamilies Orchidoideae and Epidendroideae (Freudenstein and Rasmussen 1996, Vij et al. 2005, Bhanwra et al. 2006a, b, Kant and Bhanwra 2010, Kant and Hossain 2010). The archesporial cells underwent mitotic divisions and differentiated into sporogenous cells and thecae became elliptic, bending towards the labellum. Cells of the hypodermal layer increased in size and functioned as primary parietal cells (Figs $1 \mathrm{j}, \mathrm{k}$ ).

Anther wall was formed from sporogenous cells of the hypodermal layer in both the species which was similar to Zeuxine strateumatica (Kant and Bhanwra 2010) and Malaxis muscifera (Kant and Hossain 2010). However, only few earlier reports have clarified about the origin of anther wall in orchids because most of the studies carried out only at pollen mother cell stage. Primary parietal cells underwent asynchronous periclinal divisions to form an outer secondary parietal layer (OSP) and an inner secondary parietal layer (ISP) (Figs 1l, m). A provascular tissue became evident in the connective region. Due to more growth in the connective region and abaxial surface of anther, the thecae further bent towards the labellum and came to lie side by side. At this stage, cells in the center of each theca became vacuolated and formed a dorsiventral septum 


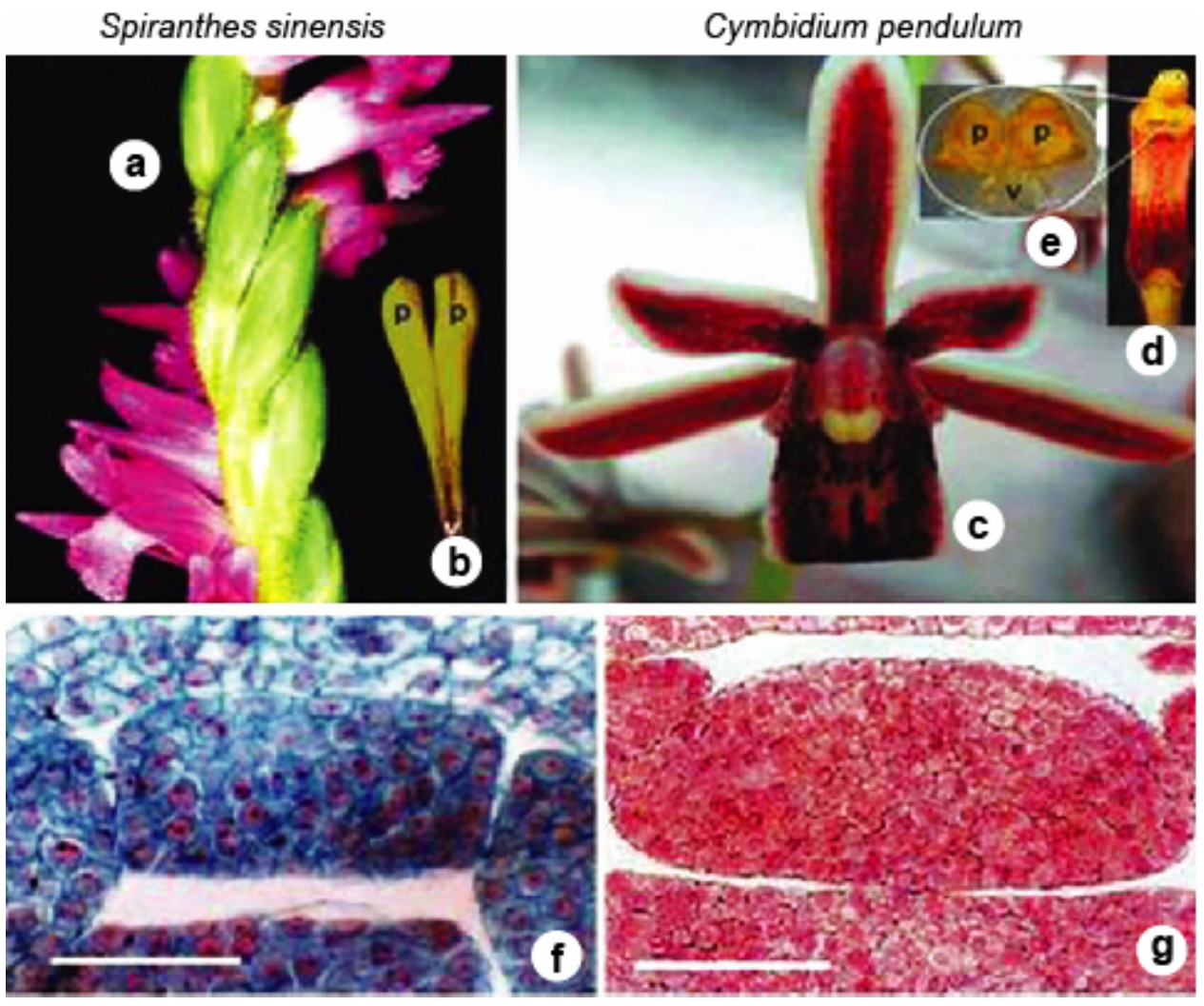

Fig. 1. Anther morphology and different developmental stages of anther in Spiranthes sinensis and Cymbidium pendulum: a. An inflorescence of Spiranthes sinensis, b. Pollinariun unit of Spiranthes sinensis with viscidium and two bipartite pollinia, c. A flower of Cymbidium pendulum, d-e. Ventral view of gynostemium and pollinariun unit Cymbidium pendulum, f-g. Anther primordial. ( $\mathrm{p}=$ pollinium, $\mathrm{v}=$ viscidium, $\mathrm{op}=$ operculum). (Scale bars, $\mathrm{f}=50 \mu \mathrm{m} ; \mathrm{g}=100 \mu \mathrm{m})$.

(Figs 2a,b). In S. sinensis, the septum was complete, 6-layered and extended from the connective to the apex of each theca, whereas, in C. pendulum, septum was partial, about 10-layered and developed as an arc of the sterile tissue. The outer secondary parietal layer directly functioned as endothecium.

In S. sinensis, cells of ISP layer divided periclinally into 2-layers, of which inner one differentiated into outer tapetum whereas, in C. pendulum, ISP layer divided periclinally into 3layers, of which, inner one differentiated into outer tapetum. Thereafter, the outer tapetum divided periclinally and became 2-layered. In both taxa, outer most cells of septum differentiated into tapetum-like cells called 'inner tapetum' which aligned with the outer tapetum. At many places, the endothecial cells were 2-layered in S. sinensis, while it remained single layered in C. pendulum.

The sporogenous cells differentiated into pollen mother cells. At this stage, the anther wall was fully developed. It was 4 - 5 layers in S. sinensis which was similar to Z. strateumatica (Kant and Bhanwra 2010). On the other hand, a 7-layered anther wall was formed in $C$. pendulum (Figs 2c, d). Two-layered tapetum was observed in Cymbidium which is a new report for this genus. The subfamily Epidendroideae shows a remarkable variation where anther wall 
may be 4, 5, 6 or even 7-layered due to 1-3 middle layers and 1-2 layered tapetum. Generally, a 4-layered anther wall is designated as 'Monocotyledonous' type but more than 4-layered anther wall is called 'Massive' type (Sood and Rao 1988) that supports the present investigation. In C. pendulum, anther wall underwent repeated mitotic divisions and formed an anther beak facing the rostellum. Similar observation was also reported in C. aloifolium (Bhanwra et al. 2006a). However, it was absent in S. sinensis.

Spiranthes sinensis
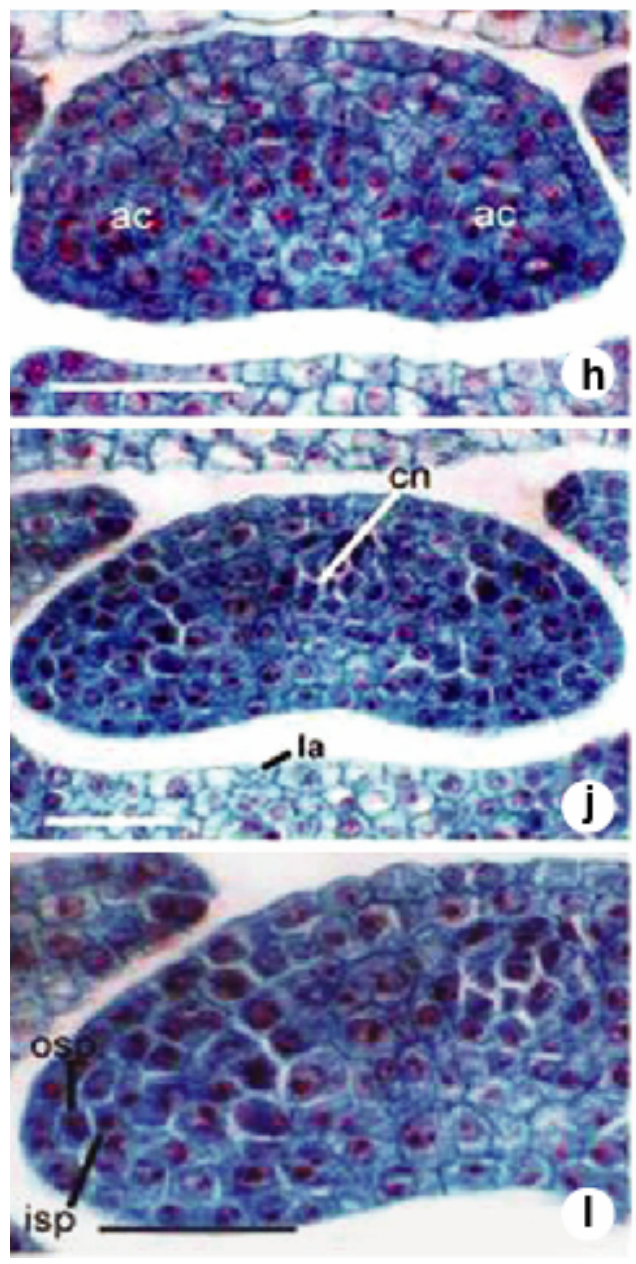

\section{Cymbidium pendulum}
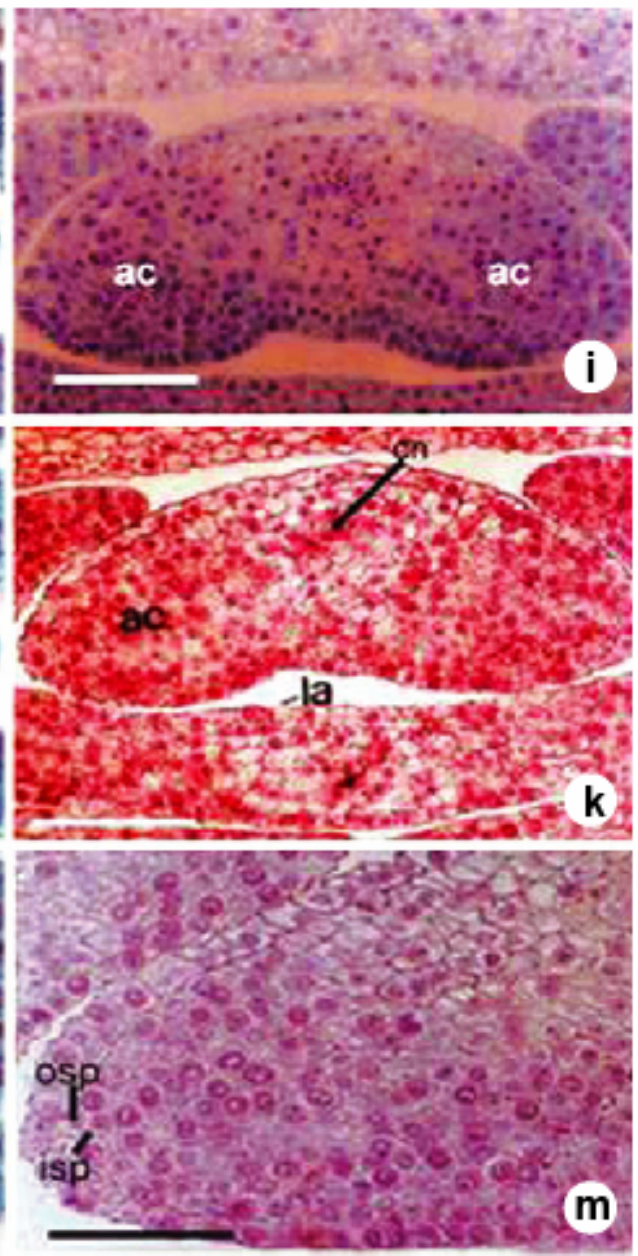

Fig. 1 Contd. h-i. Anther primordia oriented towards the labellum (ac=densely cytoplasmic archesporial cells), $\mathrm{j}-\mathrm{k}$. Anther primordia at advanced stage of development ( $c n=$ connective tissue), $\mathrm{l}-\mathrm{m}$. Formation of outer secondary parietal layer (osp) and inner secondary parietal layer (isp). (Scale bars, h, j, l, m = $50 \mu \mathrm{m} ; \mathrm{g}, \mathrm{i}, \mathrm{k}=100 \mu \mathrm{m})$.

The pollen mother cells underwent asynchronous meiotic cell divisions in both the species. Simultaneous cytokinesis followed by meiosis resulted microspore tetrads formation. In $S$. sinensis, microspore tetrads separated out from each other, whereas, in C. pendulum, tetrads further united to form a pollinium in each theca. Simultaneous cytokinesis and formation of 
different type of microspore tetrads in varied percentage is a common feature in Orchidaceae (Sood and Rao 1988) except few taxa where cytokinesis is of successive type (Swamy 1943, Arekal and Karanth 1981, Aybeke 2012).

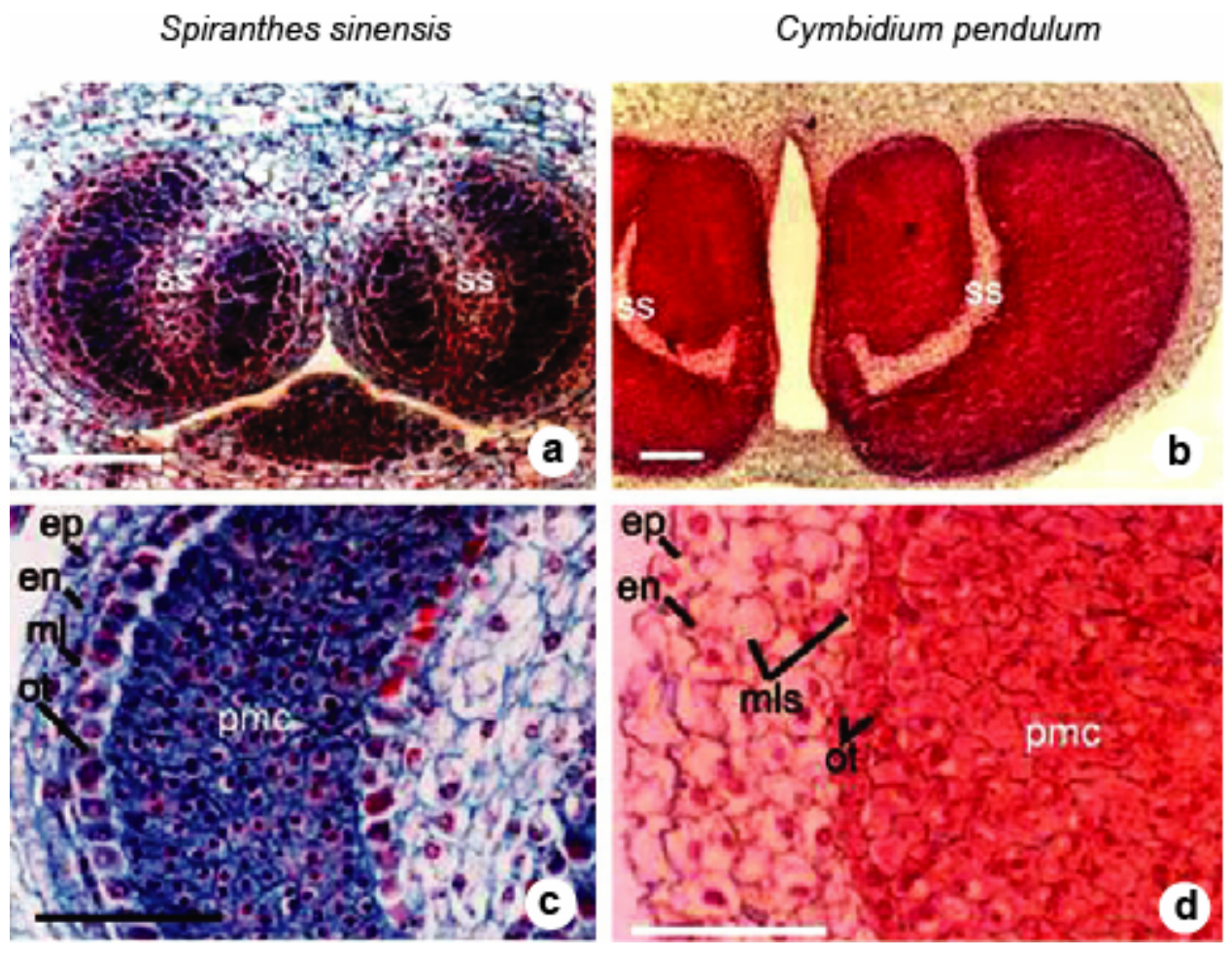

Fig. 2. Different developmental stages of anther and pollen micomorphology of Spiranthes sinensis and Cymbidium pendulum: a-b. Two thecae lie side by side (ss = sterile septum), c- d. Anther at pollen mother cell stage (pmc) and its differentiation [ep = epidermis, en = endothecium, mls = middle layers and ot $=$ tapetum]. [Scale bars, a-d $=100 \mu \mathrm{m}]$

During microgametogenesis, each microspore produced a smaller, lenticular, generative cell and a larger 'spherical' vegetative cell. The mitotic divisions was asynchronous which may be due to weak cytoplasmic connections between the adjacent microspores (Figs 2e-h). A similar mode of male gametophyte development has been reported in some other orchids (Swamy 1949, Sood 1989, 1992, Gupta 2003, Aybeke 2012). In S. sinensis, the endothecial layers developed fibrous thickenings similar to Z. strateumatica (Kant and Bhanwra 2010), whereas in C. pendulum, middle layers developed fibrous thickenings that morphologically similar to those of endothecium as reported in most of the epiphytic orchids (Gupta 2003, Bhanwra et al. 2006a). The tapetal cells completely degenerated during the microgametogenesis. In each theca, cells of the septum started their degeneration near the stomium and then proceeded towards the connective. It resulted into 2 perforate pollinia in C. pendulum and 2 ovoid and soft bipartite pollinia in S. sinensis (Figs 2i, j).

Pollen grains were monoaperturate, exine sculpturing was reticulate bearing 'muri' on the surface, and cytoplasmic connections were not visible in S. sinensis (Fig. 2k). Reticulate type of pollen sculpturing was reported in the subfamilies Orchidoideae and primitive Epidendroideae e.g. 
tribe Neottieae (Ackerman and Williams 1980, Lumaga et al. 2006). Whereas in C. pendulum, pollen grains were either monoaperturate or inapurturate, exine sculpturing was of tectate type, and cytoplasmic connections were clearly visible (Fig. 2l). These pollen characters indicated the advance evolutionary features of $C$. pendulum among the Epidendroideae (Kapil and Arora 1990). Shedding units were tetrads in both S. sinensis and C. pendulum. Mode of pollen dispersion is an important character for Orchidaceae. In sub-family Orchidoideae, pollen grains are grouped as soft pollinia and the dispersal units are mostly massulae except tetrads in a few taxa. In sub-family Epidendroideae, pollen grains are grouped into hard pollina, however, the shedding units are either monads, tetrads or massulae in the primitive taxa and hard pollinia in the advanced taxa (Singer et al. 2008).
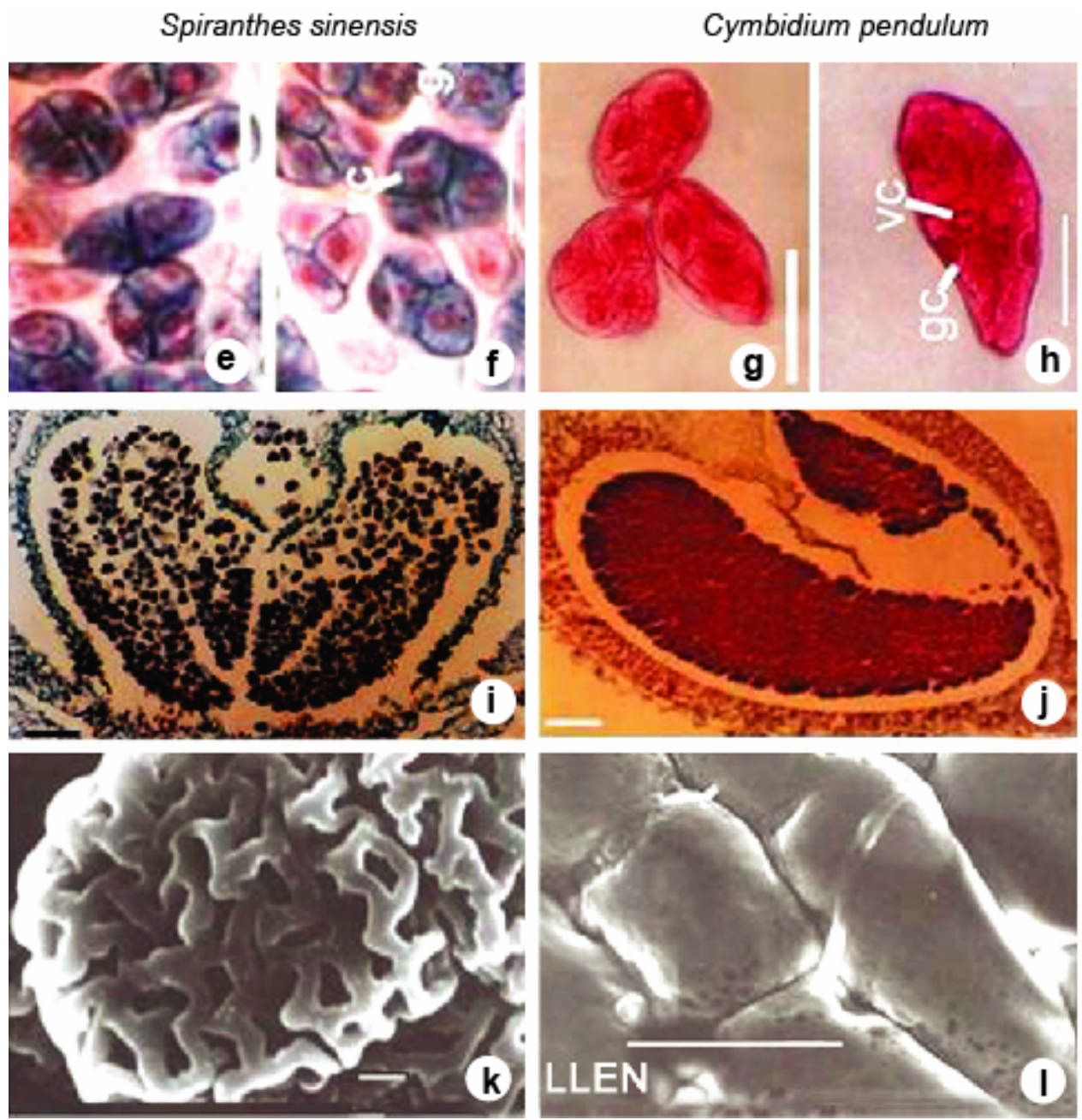

Fig. 2 Contd. e-h. Microspores at different stages of mitosis $(v c=$ vegetative cell, $g c=$ generative cell), i-j. Pollinia with pollen grains, k. Mature pollen grain with reticulate exine and presence of 'muri' at the surface, l. Pollen grain with tectate type sculpturing and presence of small pits at peripheral regions.

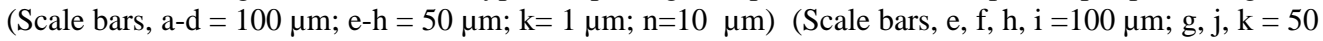
$\mu \mathrm{m} ; \mathrm{l}=10 \mu \mathrm{m})$. 
Although the two orchid species of different habitats under study share some common characters were markedly different from one another in a number of features. Anther characters have immense importance in orchid taxonomy; however, information on anther or pollinium development and pollen micromorphology is insufficient for this large and highly evolved family of flowering plants. Therefore, the findings of the present investigation will obviously provide strong support for classification and character evolution of the Orchidaceae.

\section{References}

Ackerman JD and Williams NH 1980. Pollen morphology of the tribe Neottieae and its impact on the classification of the Orchidaceae. Grana 19: 7-18.

Arekal GD and Karanth KA 1981. The embryology of Epipogium roseum (Orchidaceae). Plant Syst. Evol. 138: $1-7$.

Aybeke M 2012. Anther wall and pollen development in Ophrys mammosa L. (Orchidaceae) Plant Syst. Evol 298: 1015-1023.

Bhanwra RK, Vij SP, Chandel V, Kant R and Dutt S 2006a. Development of pollinium in two epidendroid orchids. Curr. Sci. 90: 1384-1388.

Bhanwra RK, Vij SP, Kant R, Chandel V and Dutt S 2006b. Pollinium development in Epipactis veratrifolia. J. Orchid Soc. India 20: 1-6.

Cameron KM, Chase MW, Whitten WM, Kores PJ, Jarrell DC, Albert VA, Yukawa T, Hills HG and Goldman DH 1999. A phylogenetic analysis of the Orchidaceae: evidence from $r b c L$ nucleotide sequences. Amer. J. Bot. 86: 208-224.

Freudenstein JV and Rasmussen FN 1996. Pollinium development and number in the Orchidaceae. Amer. J. Bot. 83: 813-824.

Gupta V 2003. Orchid pollinaria - some salient features. J. Orchid Soc. India 17: 43-55.

Gurudeva MR and Govindappa DA 2008. Ontogeny and organization of female gametophyte in Epidendrum radicans Pavon. Ex Lindl. (Orchidaceae). J. Orchid Soc. India 22: 73-76.

Gutierrez RMP 2010. Orchids: A review of uses in traditional medicine, its phytochemistry and pharmacology. J. Med. Plant Res. 4: 592-638.

Kant R and Hossain MM 2010. Pollinium development and associated changes in anther in Malaxis muscifera (Lindl.) Kuntze. Bangladesh J. Bot. 39: 193-198.

Kant R and Bhanwra RK 2010. Development of anther in relation to sectile pollinium in Zeuxine strateumatica (Lindl.) Schltr. J. Biol. Life Sci. 1: 5-12.

Kapil R.N. and S. Arora. 1990. Some fascinating features of orchid pollen. J. Orchid Soc. India 4: 9-28.

Lumaga BMR, Cozzolino S and Kocyan A 2006. Exine micromorphology of Orchidinae (Orchidoideae, Orchidaceae): Phylogenetic constraints or ecological influences? Ann. Bot. 98: 237-244.

Singer RB, Gravendeel B, Cross H and Ramirez SR 2008. The use of orchid pollinia or pollinaria for taxonomic identification. Selbyana 29: 6-19.

Sood SK 1989. Embryology and systematic position of Liparis (Orchidaceae). Plant Syst. Evol. 166: 1-10.

Sood SK 1992. Embryology of Malaxis saprophyta, with comments on the systematic position of Malaxis (Orchidaceae). Plant Syst. Evol. 179: 95-105.

Sood SK and Rao PRM 1988. Studies in the embryology of the diandrous orchid, Cypripedium cordigerum (Cypripedieae, Orchidaceae). Plant Syst. Evol. 160: 159-168.

Swamy BGL 1943. Embryology of the Orchidaceae. Curr. Sci. 12: 13-17.

Swamy BGL 1949. Embryological studies in Orchidaceae I. Gametophytes. Amer. Midl. Natural. 41: 184201.

Vij SP, Kaur P, Kaur S and Kaushal PS 1992. The orchid seeds: taxonomic, evolutionary and functional aspects. J. Orchid Soc. India 6: 91-107. 
Vij SP, Bhanwra RK, Dutt S, and Nayyar H 2005. Development of anther and male gametophyte in Rhynchostylis retusa $\mathrm{Bl}$. (Orchidaceae). Phytomorphology 55: 93-101.

Yoganarasimhan SN 1996. Medicinal Plants of India, Vol. I. Karnataka Interline Publishing Pvt. Ltd., Bangalore, India.

(Manuscript received on 28 April, 2012.; revised on 10 November, 2013) 